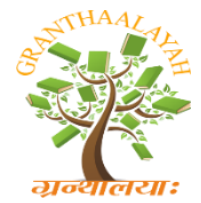

\author{
INTERNATIONAL JOURNAL OF RESEARCH - \\ GRANTHAALAYAH \\ A knowledge Repository
}

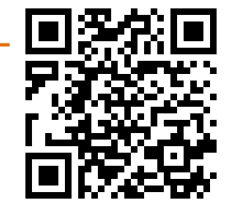

Management

\title{
THE EFFECTS OF TRANSACTIONAL AND TRANSFORMATIONAL LEADERSHIP ON PERSONNEL CONDUCT
}

\author{
Nyuonguo Kenneth Nsom ${ }^{1}$, Margaret Maih Teih ${ }^{2}$, Fabian Sundjo ${ }^{3}$ \\ ${ }^{1}$ MBA, EMBA, Assistant Administrator, Cameroon Baptist Convention Health Services / \\ Doctoral Student, Unicaf University of Zambia \\ ${ }^{2}$ MSc, Cameroon Baptist Convention Health Services, Cameroon \\ ${ }^{3} \mathrm{PhD}$, Lecturer, University of Bamenda, Cameroon
}

\begin{abstract}
The focus of this paper has been to present how transactional and transformational leadership styles affect personnel conduct. A review of the literal works of others in relation to the practical application of these leadership styles as observed in the management of projects and the Cameroon Baptist Convention Health Services (CBCHS) central administration leadership, has been the inspiration to the conclusions made. From the empirical qualitative study conducted on 30 personnel, transactional leadership is all about personnel providing services, receiving payment (rewards) and or sanctions from the leadership. Results indicates that subordinates are either praised for hard work or sanctioned for failure to provide results or to meet up expectations as attested by 53\% of the respondents. However, 60\% observation indicates that transactional leadership through remuneration will facilitate goal attainment but general observation from the organization from full time employees, indicates that it will demotivate staff and slow down work. Interviews with some technical staff on the type of leadership style practiced by the department on project sites proved that transactional leadership has a negative impact on personnel conduct and can likely lead to the non-completion of projects. On the other hand, following the qualitative assessment, observation from the practice of transformational leadership style by the CBCHS central administration top leadership proves that the leadership style is primordial if leadership want to continue attend the goals of the organization and should be continue to be practiced. $86.7 \%$ of the personnel feel comfortable with the transformational leadership style of the top leadership style of the organization.
\end{abstract}

Keywords: Transactional Leadership; Transformational Leadership; Personnel Conduct.

Cite This Article: Nyuonguo Kenneth Nsom, Margaret Maih Teih, and Fabian Sundjo. (2019). "THE EFFECTS OF TRANSACTIONAL AND TRANSFORMATIONAL LEADERSHIP ON PERSONNEL CONDUCT.” International Journal of Research - Granthaalayah, 7(6), 155-164. https://doi.org/10.29121/granthaalayah.v7.i6.2019.784. 


\section{Introduction}

\subsection{Background of the Study}

Some employers at times lack the ability or the desire to assume their responsibility (Messick \& Kramer, 2004). Additionally, the specific situation helps determine the most effective style of interactions at a given time. In this light, leaders at times have to handle problems that require immediate solutions without consulting followers. In this light, Messick and Kramer (2004) suggested that the effectiveness of leadership traits or how leadership affect workforce behavior depends not only on an individual's personality but, it is also affected by characteristics of the circumstances and culture of the organization. Leadership technique in an organization is the main foundation that affects it in a significant way which attracts or retards the interest of the leader and his/her commitment with the organization (Grant, 2016). According to the findings of George \& Evanthia (nd) leadership is the ability to lead and influence others towards a goal. Also, Evanthia (nd) indicated that a leader must have followers and to gain followers requires influence and integrity. Leadership to Caldwell, Hayes, \& Long (2010) is the process of leading, guiding, and influencing individuals or a group of people to achieve a common goal. These indications of Caldwell, et al. (2010) were further supported by Jeff (2018).

There are different types of leadership styles and these affect workforce behavior differently. St. Thomas University (2018), Flickr (2012) and Braden (2019) amongst other studies, identified different leadership styles such as; democratic, autocratic, strategic, facilitative/team, transformational, cross-Cultural, Laissez-faire, transactional, Charismatic, Visionary, and Coaching Leadership styles. Among the different leadership styles, are transactional and transformational leadership. The goal of this paper is to critically assess how transactional and transformational leadership affect workforce behavior. In essence, the impact of transactional and transformational leadership on personnel conduct is the main goal to achieve in this paper.

\subsection{Statement of the Problem}

Conventional wisdom indicates that when people work they need to be motivated and this can be financial or non-financial. Burns (1978) as cited by Khalil et al. (2016) opined that rewards and incentives play a key role in the motivational level of the employees. In the other hand, Khalil et al., (2016) opined that transformational leadership is much better because it motivates others to do more than they originally intended or thought possible. They set more challenging expectations and typically achieve higher performance. Statistically, transformational leadership tends to have more committed and satisfied followers

Despite the indication of Burns (1978 and Khalil et al. (2016), organizations and individuals who practice transactional leadership, seems not to have employee - employer leadership touch and vice versa. Instead, organizations that practice transformational leadership styles seem more relational and with an intimate employee - employer (leadership) touch.

Considering the aforementioned, there has not been much assessment on the impact of either transactional or transformational leadership styles so that those who practice it can better follow to the best of our knowledge. This article purports to cover this gap. 


\subsection{Study Objectives}

The main objective of this paper to assess the impact of transactional and transformational leadership styles on workforce behavior. Specifically;

1) To know the leadership style among transactional and transformational leadership styles that positively affect personnel conduct at workplace than the other

2) To understand the differences or similarities between the two leadership styles

\subsection{Research Questions}

1) Which of the two leadership styles (transactional/ transformational) positively affect personnel conduct at workplace than the other?

2) Are there any differences or similarities between the two leadership styles?

\subsection{Study Hypotheses}

HO: Transformational Leadership has high positive affect on workforce behavior H1: Transactional Leadership has very little positive effect on workforce behavior.

\subsection{Significance of the Study}

This assessment is so important in that it will portray the impact of both transactional and transformational leadership styles on workforce behavior at workplace. It will help to project which of the leadership styles have a high positive impact on personnel conduct. This will help management of organizations as well as project organizations to better peruse which of the two leadership styles can better impact the services positively.

\subsection{Definition of Terms}

Transactional leadership: from the findings of Khalil, Iqbal \& Khan (2016), transactional leadership is a leadership that involves an exchange process whereby followers get immediate, tangible rewards or sanctions for carrying out the leader's orders or for failing to do so and that this type of leadership maintains the status quo.

Transformational leadership: On the other hand, Khalil et al. (2016) indicated that transformational leadership is all about initiating change in organizations, groups, oneself and in others.

Personnel conduct: According to Northouse (2016), personnel conduct simply refers to workforce behavior.

\section{Materials and Methods}

\subsection{Differences between Transactional and Transformational Leadership}

From the above results, wenlinked to Ronald (1998), Joseph (2015), Surbhi (2015), and UK Essay (2017) in their different findings, to indicated the following major differences between 
transactional and transformational leadership: Compensation and punishment are used in transactional leadership as a basis for correcting the followers but charisma and enthusiasm is used to influence followers by a transformational leadership (Joseph, 2015). Joseph (2015) further indicated that in a transactional leadership, stress is placed on the leaders connection with followers meanwhile, stress is laid on the values, beliefs and needs of the leader and followers in the transformational leadership. From the aforementioned, the $86.7 \%$ were happy with transformational leadership while only 53\% saw value in transactional. Surbhi (2015) indicated that transactional leadership is reactive whereas transformational leadership is proactive and also that transactional leadership is best for a stable setting, while transformational leadership is good for the wild setting. And this is confirmed by UK Essay (2017). Northouse (2016) stressed that transactional leadership works for refining the present circumstances of the organization and on the other hand, transformational leadership works for shifting the present circumstances of the organization to a better one.

Ronald (1998) pronounced that transactional leadership is bureaucratic while transformational leadership is charismatic which is in line with the findings of Northouse (2016). Transactional leadership gives room for only one leader in a group but there can be more than one leader in a group in transformational leadership (Joseph, 2015). From the indications of UK Essay (2017), transactional leadership is focused on planning and execution which is different from transformational leadership that focuses on promoting innovation. Khalil et al. (2016) stressed that followers feel more satisfied and work more effectively under a transformational leadership style than in a transactional leadership style. Our above findings confirmed this maxim. Transformational leadership leader stimulates followers to do more than originally expected. Furthermore, when employees are motivated to perform more than they could do in normal circumstances, productivity is increased. Comparing transactional and transformational leadership, the differences appear to be huge and placing transformational leadership as the best.

\subsection{Similarities between Transactional and Transformational Leadership}

Bass (1990) on the similarities of transactional and transformational leadership indicated that the model is still related. Bass (1985) as cited by Hartog, Deanne, Van, Jaap, \& Koopman (1997), stressed that though transactional and transformational leadership are of separate domains, the leader can still be both transactional and transformational. The percentage that accepted sanctions to be a means of achieving productivity in both leadership styles were below $50 \%$ measuring 46.7\% for transactional and $13.3 \%$ for transformational leadership. Hartog et al. (1997) said Bass (1985) argues that transformational leadership builds on transactional leadership and not vice versa. The similarity is that transformational leadership builds on transactional leadership. According to Hartog et al. (1997), transformational leadership can be viewed as a distinct case (improved) of transactional leadership, though both approaches are linked to the achievement of some goals. For example, transactional leadership encourages productivity as attested by the 53\% and $86.7 \%$ for transactional and transformational leadership styles respectively. Both have a clear structure, and it allows employees to control compensation and make goals achievable which are seen as its advantages. 


\subsection{Empirical Literature}

Khalil, Iqbal \& Khan (2016) opined that transactional leadership is a leadership that involves an exchange process whereby followers get immediate, tangible rewards for carrying out the leader's orders and that this type of leadership maintains the status quo. Burns (1978) as cited by Khalil et al. (2016) opined that rewards and incentives play a key role in the motivational level of the employees. According to Johnson (2017) managers using the transactional leadership style, due receive certain tasks to perform and provide rewards or punishments to team members based on performance results. On the other hand, Khalil et al. (2016) indicated that transformational leadership is all about initiating change in organizations, groups, oneself and in others. They set more challenging expectations and typically achieve higher performance. Statistically, transformational leadership tends to have more committed and satisfied followers (Khalil et al., 2016). The study of Johnson (2017), pointed out that transformational leadership encourages communication. The findings of Joseph (2015) hold that transformational leadership motivates team members or followers to do more than are expected and this increases productivity.

Following the aforementioned, we find a gap in that no comparism seems to have been drawn between the two to better understand which one affect personnel conduct more and in what setting can each be better perused. Secondly, since both leadership styles are geared toward productivity, which one of them brings in better output. This present assessment will bridge the gap.

\subsection{Methodology}

This qualitative assessment, took a descriptive research approach to ascertain how transactional and transformational leadership styles affect workforce behavior. The leadership style practice at the CBCHS Central administration was simply assessed compared to that practice by the technical services department on project sites. This was because we were certain of the leadership style (transformational leadership) that the central administration of the CBCHS practices while the technical services department practices mostly transactional leadership.

The two concepts (transactional and transformational leadership) were first explained to the participants before their views were gotten. Transactional and transformation leadership information were obtained from a project site from some permanent employees at central administration through observation and interview. A total of 30 employees were sampled.

Information provided by the participants were jealously and privately kept secret in observant to the principle of anonymity, privacy and confidentiality.

The interview technique and observations were made by the researcher in person to be sure of the validity and reliability of the instruments used and data collected. 


\section{Results}

\subsection{Transactional Leadership}

Table I: How transactional leadership affect personnel conduct at work place

\begin{tabular}{|l|l|l|l|}
\hline \multicolumn{3}{|c|}{ How transactional leadership affect personnel conduct at work place } \\
\hline \multicolumn{1}{|c|}{ Independent Variable } & Frequency & $\begin{array}{c}\text { Percentage of positive } \\
\text { effect (\%) on personnel } \\
\text { conduct }\end{array}$ & Significance \\
\hline Happy with task work with daily or wages & 12 & $60 \%$ & $*$ \\
\hline $\begin{array}{l}\text { Happy } \\
\text { Remuneration }\end{array}$ & $40 \%$ & $*$ \\
\hline Sanction encourages productivity & 14 & $46.7 \%$ & $*$ \\
\hline $\begin{array}{l}\text { The leadership style (remuneration/ } \\
\text { sanction) encourages productivity }\end{array}$ & 16 & $53 \%$ & $*$ \\
\hline
\end{tabular}

$(-=0-39 \%, *=40-60 \%, * *=61-80 \%, * * * 81-100 \%)$

Table I above shows a quick assessment of how transactional leadership style affect personnel conduct. Following the four independent variables studied, 18 (60) workers proved that they are happy with task work payment in transactional leadership, against 12 (40\%) who prefer daily or monthly wages. $14(46.7 \%)$ were confortable to be productive with sanctions provided by such a leadership styles while only 16 (53.3\%) says such a leadership style encourages productivity.

\subsection{The Effects of Transactional Leadership on Personnel Conduct}

Following the above, this leadership style maintains or continues the status quo. It is also the leadership that involves an exchange process whereby followers get instant, palpable rewards for carrying out the leader's orders (Khalil, Iqbal \& Khan, 2016). Following a project carried out at the North West Special Fund for Health Project at the Bamenda regional hospital in 2012, the investigator happened to be the main project manager and put to practice a complete transactional leadership style at some points and transformational in the other. The transactional leadership tendencies were mostly for task work to be paid on piece rate following the task accomplished where the workers worked harder and to accomplish task on time and received their instant payment. This yielded some fruits in line with the $60 \%$ observed but some rushed to finish their task on time but lower the quality of the work and some merely wasted the materials. However, it was not the best in all circumstances as some workers became more demotivated that some were earning more than they do just because they were paid on daily or monthly rate compared to those paid on piece rate or task work confirming to the $40 \%$ observed. Burns (1978) as cited by Khalil et al. (2016) opined that rewards and inducements play a vital role in the motivational level of the employees. The motivation depends too on the sub cluster in which it is categorized. The transactional leadership style is classified into three main sub clusters; contingent rewards, active management, and passive management. Following this grouping, the leadership is erected on the hypothesis that team members must agree to obey their leader and accepting the working task assigned to them. Bass (1990) refers this style of leadership as one that focuses on the payment of team members in return for their hard work and submission on the working task. According to Johnson (2017) leaders using the transactional leadership style, accepts definite responsibilities to 
perform and provide compensations or penalties to team members based on the results of their performance. From the above results, only $43.3 \%$ were comfortable with sanctions while $46.7 \%$ were not comfortable with such a leadership style. Transactional leadership sound elementary, with its focus on exchange. As observed and noted from some of the Technical Department team members, the team in transactional leadership can decide to mess-up the work and can be more resistant since they are aware that the leader does not necessary value them but their services which is dangerous to the organization.

Transactional leadership brings leaders and group members together to set planned goals, and workers agree to follow the direction and leadership of the leader to achieve those goals for compensation and as well can chose to disobey the superior as a team (Bass, 1990). The studies of Ronald (1998) revealed that the manager or leader holds authority to appraise results and train or correct personnel when the team members fail to meet goals. Additionally, personnel receive compensation, when they realize goals. Some importance of transactional leadership is that clear instructions are given to subordinates, the team focuses on expectations as well as giving feedback (Hater \& Bass, 1988). Northouse (2016) opined that transactional leadership signifies the majority of leadership models, which concentrates on the connections that happen between leaders and their followers. We see politicians who win votes by promising payments such as jobs, good roads and no new levies, as a good example of transactional leadership.

Talking on how transactional leadership affects personnel conduct, Joseph (2015) affirmed that it compensates performance, disciplines those who fail to attain desired goals, and that the leader is passive to the concerns of the personnel and as well, inflexible to change. Also, such a leader places a lot of importance on commercial arrangement and beliefs and wants things to go as scheduled irrespective of whether they were wrongly prearranged. In fact such a leadership style builds a stiff organizational pyramid that is resistant to change. Report on an issue, is expected to pass through all immediate leaders before reaching the top management (Northouse, 2016). If the hierarchy is avoided, it might be considered as disobedience. This leadership can rather promote egotism than overall interest. For example; the leader's interest is to achieve his goals while the employee's interest is to get their pay or compensation (Bass, 1990). However, the individual worker's inspiration for greater compensation in transactional leadership is determined by his or her input and as such, the personnel work harder to receive higher earnings and this drive for higher earnings equally increases productivity (Joseph, 2015).

\subsection{Transformational Leadership}

Table II: How Transformational Leadership Affect Personnel Conduct at Work Place

\begin{tabular}{|l|l|l|l|}
\hline \multicolumn{3}{|c|}{ How transformational leadership affect personnel conduct at work place } \\
\hline \multicolumn{1}{|c|}{ Independent Variable } & Frequency & $\begin{array}{c}\text { Percentage of positive } \\
\text { effect (\%) on personnel } \\
\text { conduct }\end{array}$ & Significance \\
\hline Happy with task work daily or wages & 28 & $6.7 \%$ & - \\
\hline $\begin{array}{l}\text { Happy with } \\
\text { Remuneration }\end{array}$ & 2 & $93.3 \%$ & $* * *$ \\
\hline Sanction encourages productivity & 4 & $13.3 \%$ & - \\
\hline
\end{tabular}




\begin{tabular}{|l|l|l|l|}
\hline $\begin{array}{l}\text { The leadership style (inspiring, } \\
\text { motivational, and initiating change) } \\
\text { encourages productivity }\end{array}$ & $86.7 \%$ & $* * *$ \\
\hline
\end{tabular}

$(-=0-39 \%, *=40-60 \%, * *=61-80 \%, * * * 81-100 \%)$

From the table II above, $28(93.3 \%)$ are happy with daily or monthly payment under transformational leadership. 26 (86.7) salute transformational leadership as an idle that inspires, motivates, and initiates change which both encourages productivity at work place.

\subsection{The Effects of Transformational Leadership on Personnel Conduct}

Khalil et al., (2016) opined that transformational leadership is a process of initiating change in organizations, groups, among others. Such a leadership motivates others to do more than they initially anticipated. The transformational leader sets more challenging expectations and achieves higher performance. Arithmetically, this form of leadership tends to have more loyal and fulfilled followers (Khalil et al., 2016). This is mainly so because such a leadership empowers followers. The transformational leadership style relies on high levels of communication from management to meet goals at the workplace (Johnson, 2017). The leader inspires workers and boosts productivity and efficiency through communication and high eminence. This style of leadership requires the involvement of management to meet goals (Zach, 2018). Leaders focus on the big picture within an organization and give lesser responsibilities to the team to realize its goals. Such a leadership style has the potential that inspires and motivates the group to work for a common goal as well as boast Communication, participation and respect in the workplace (Fox, Rejeski \& Gauvin, 2000).

Edoka (2012) indicated that effective leadership is an efficient foundation of managing development because it stands competitive advantage for the improvement of organizational performance. Joseph (2015) holds that transformational leadership motivates team members or followers to do more than what is expected which increases productivity. This is better done through the lifting of the followers' levels of cognizance towards the importance and significance of particular goals. It also aids followers to surpass their own self-interest for the sake of the group or the organization, and shifting the current followers' needs to higher standards level.

\section{Conclusion}

The main focus of this paper was to assess how transactional and transformational leadership affect workforce behavior or better still, to assess the impact of both transactional leadership and transformational leadership on personnel conduct. Normally, a comprehensive leadership style should have some elements of the other styles in some aspects and for some particular purposes. Transactional leadership style involves an exchange process, which the followers get direct and touchable rewards for carrying out the orders of the leader or receives sanctions for failing to carry out the leader's orders (Khalil, Iqbal \& Khan, 2016). Some task work such as in project sites and stable settings need transactional leadership style to meet up with time. The challenge is that poor quality work can be achieved since those on task work will want to focus more on completing the task and undermining quality. It can also demotivate employees especially in large organization. This leadership style has less positive impact on workforce behavior and should be practiced with care not to create an environment saturated by position, power, and politics. 
On the other hand, transformational leadership is all about motivating/ inspiring workers and initiating change in organizations, and groups to achieve higher performance thereby attracting more committed followers. The differences among the two leadership styles are huge with little similarities (Hater \& Bass, 1988). Transformational leadership fit well in any setting if practiced in context. It is good for a wild environment and even unstable systems. It has a positive effect on personnel conduct and productivity at workplace. Transactional leadership negatively affect personnel conduct, but not completely bad because it still promote hard work, however, transformation leadership is far much appreciated in that it highly positively affect personnel conduct. It initiates change in organizations, groups, and oneself to achieve higher performance thereby attracting more committed followers (Khalil et al., 2016). Following the aforementioned, we believe that our objectives have been satisfactorily met.

\section{References}

[1] Bass, B. M. (1990). From transactional to transformational leadership: Learning to share the vision. Organizational dynamics, 18 (3), 19-31. Retrieved from, https://www.sciencedirect.com/science/article/pii/009026169090061S

[2] Braden, B. (2019). The 7 Most Common Leadership Styles \& How to Find Your Own. HubSpot, Inc. Retrieved from, https://blog.hubspot.com/marketing/leadership-styles.

[3] Caldwell, C., \& Hayes, L. A. (2010). Leadership, trustworthiness, and ethical stewardship. Journal of Business Ethics, 96 (4), 497-512. Retrieved from, https://link.springer.com/article/10.1007/s10551-010-0489-y.

[4] Edoka, J. (2012). Leadership is seen as a Potent Source of Management Development and Sustained Competitive advantage for Organizational Performance Improvement. University of Nigeria Virtual Library. Retrieved from, www.unn.edu.ng/publications/files/images/JOHN\%20EDOKA.pdf

[5] Flickr, S. (2012), Six Leadership Styles, And When You Should Use Them. Career evolution. Retrieved from, https://www.fastcompany.com/3034803/templates-and-hints-for-the-perfectemail-for-almost-every-situation

[6] Fox, L. D., Rejeski, W. J., \& Gauvin, L. (2000). Effects of leadership style and group dynamics on enjoyment of physical activity. American Journal of Health Promotion, 14(5), 277-283. Retrieved from Unicaf University Website.

[7] George, A. B. \& Evanthia, P. V (nd). Leadership vs Management. LUND University Campus Helsingborg. Retrieved from, https://www.ep.liu.se/ecp/026/076/ecp0726076.pdf

[8] Grant, N. (2016). Team work makes the dream work. Amanda's Blog. Retrieved from, www.scientific America, how Diversity Makes us Smarter - Scientific America

[9] https://en.wikipedia.org/wiki/Diversity_(business)rio2016.olympics.com.

[10] Hartog, D., Deanne, N. Van, M., Jaap, J. \& Koopman, P. L. (1997). Transactional versus transformational leadership: An analysis of the MLQ. Journal of Occupational and Organizational Psychology; Leicester 70 (3), 19-34. Retrieved from, https://search.proquest.com/central/docview/199340442/7B41B83DDCDD4481PQ/1?accountid= 188730

[11] Hater, J. J., \& Bass, B. M. (1988). Superiors' Evaluations and Subordinates' Perceptions of Transformational and Transactional Leadership. Journal of Applied Psychology, 73, 695-702. http://dx.doi.org/10.1037/0021-9010.73.4.695

[12] Jeff, E. (2018). What is the True Meaning of Leadership? Forbes. Retrieved from, www.Forbes.com

[13] Johnson, R. (2017), Five Different Types of Leadership Styles. Culcrattanak. Retrieved from, http://smallbusiness.chron.com/5-different-types-leadership-styles-17584.html 
[14] Joseph, C. (2015). 14 Transactional Leadership Style Examples. Joseph Chris Partners, 281, 3592175. Retrieved from, http://www.josephchris.com/14-transactional-leadership-style-examples

[15] Khalil, U., Iqbal, J. \& Khan, A. (2016). Exploring Leadership Styles of School Administrators in Pakistan. FWU Journal of Social Sciences; Peshawar 10 (1), 39-47. Retrieved from, https://search.proquest.com/central/docview/1810262544/79BDC24415B74E3APQ/6?accountid= 188730

[16] Messick, D. M \& Kramer, R, M. (2004). The Psychology of Leadership: New Perspectives and Research. Psychology Press, Amazon France. Retrieved from, https://books.google.cm/books/about/The_Psychology_of_Leadership.html?id=6Sh5AgAAQBAJ \&redir_esc $=\mathrm{y}$

[17] Northouse, P.G. (2016). Leadership: Theory and Practice. Sage edge Publications, London 7Th edition. Retrieved from https://journalhosting.ucalgary.ca/index.php/cjeap/article/view/42995

[18] Ronald, J. D. (1998). Relationship of Transformational and Transactional Leadership with Employee Influencing Strategies. Group and Organizational Journal. https://doi.org/10.1177/105960118801300404

[19] Surbhi, S. (2015). Difference Between Transactional and Transformational Leadership. Key difference. Retrieved from, https://keydifferences.com/difference-between-

[20] St. Thomas University (2018). What is Laissez-Faire Leadership? How Autonomy Can Drive

[21] Success. St. Thomas University online. Retrieved from, https://online.stu.edu/articles/education/what-is-laissezfaire-leadership.aspx

[22] UKEssay (2017). Difference between Transactional and Transformational Leader. Essay in Management. Retrieved from, https://www.ukessays.com/essays/management/differences-between-transactional-andtransformational-leadership-management-essay.php-transactional-and-transformationalleadership.html

[23] Zach, L. (2018). Five Different Types of Leadership Styles. Chron. Retrieved from, http://smallbusiness.chron.com/5-different-types-leadership-styles-17584.html

*Corresponding author.

E-mail address: nyuonguoken@yahoo.com/megforhealth@gmail.com/sundjofabien@ rocketmail.com 